Lubomira Parijkova, PhD, assoc. prof.

State University of Library Studies and Information Technologies, Butgaria

dr.parijkova@abv.bg

\title{
Bulgarian good practices for reading competence
}

\author{
Dobre praktyki w zakresie rozwoju \\ kompetencji czytelniczych w Butgarii
}

Lubomira Parijkova - PhD, associate professor, an author and initiator of many practice-oriented events, including the creation of bookcrossing area, bookcafe, awards "Homo Legens", celebration of the International Day of the Book and Copyright in State University of Library Studies and Information Technologies and a documentary film.

Dr. Parijkova is PhD in Science studies and a master of Philosophy. Her field of interests is connected with book history, reading, philosophy of the book and knowledge management. She's an author of more than 60 articles, two monographs and a textbook.

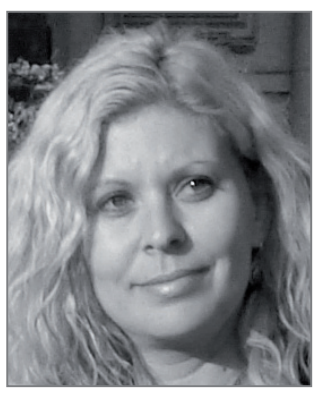

Selected publications:

- Bookcrossing and initiatives related to the exchange of books. Study and presentation of good practices for reading competence of children and students [Bookcrossing i inicjatywy związane $\mathrm{z}$ wymianą książek. Analiza i prezentacja dobrych praktyk w zakresie krzewienia kultury czytelniczej wśród uczniów i studentów], Sofia, 2013

- Government policy for reading stimulation [Polityka rządowa w zakresie stymulacji czytelnictwa] [in:] Parijkova L. (ed.) The Book - our more sensual present, Sofia, 2013

- Research of current tendencies in the field of the book and reading. Digital present and future: economic, cultural, educational, legal and technological impacts [Badania aktualnych tendencji w zakresie książki i czytelnictwa], Sofia, 2013.

Lubomira Parijkova - dr hab., profesor nadzwyczajny, autorka i inicjatorka wielu wydarzeń, w tym utworzenia strefy bookcrossingu, kafejki książkowej, nagrody "Homo Legens”, obchodów Międzynarodowego Dnia Ksiązki i Praw Autorskich w Państwowym Uniwersytecie Nauk o Bibliotece $i$ Technologii Informacyjnych oraz filmu dokumentalnego. Prof. Parijkova doktoryzowata się w obszarze filozofii i nauk. Jej obszar zainteresowań zwiazany jest z historia ksiązki, czytelnictwem, filozofia książki $i$ zarządzaniem wiedza. Jest autorka ponad 60 artykutów, dwóch monografii i podręcznika. 


\section{Acknowledgements}

I would like to thank the Bulgarian Science Fund for supporting our research in project "New Policies for Stimulating the Reading. Research of the Bookcrossing Practices in Bulgaria" (DMU 03/49) and the State University of Library Studies and Information Technologies.

\section{The role of reading and the book nowadays}

The book is a special artifact in the history of mankind. It is a value, that had a tremendous impact on the overall experience of man. Book's power is not only a cultural symbol; it preserves the past, reveals, interpret and preserve cultural tradition. The Book also transfers knowledge and messages between people; it has a socializing function.

The reading provokes human active and analytic thinking and stimulates his creative abilities. The reader has to understand a text and the process of understanding is strongly connected with rationalization and interpretation, with searching for the punctual meaning of words.

The aim of this paper is to present some good practices for reading stimulation in Bulgaria. The focus is on young people and students. The Author defines the thesis that achieving reading competence of children readers and students need to target the collaboration among agencies, schools, public and school libraries, publishers, NGOs and parents.

\section{Reading competence}

Reading is a prerequisite for almost all cultural and social activities (International Reading Association). Reading is a complex process that involves perception, identification, understanding, comprehension of texts.

The competency is seen as a set of skills, experience and knowledge of the person, in other words, it is the aim of education. On the other hand, competence is a characteristic trait of a person, an outcome of education (Chantov V. 2012, p. 330).

To conduct his activity there is necessary reader's activity and an understanding. The process of understanding is closely connected with the personal abilities of the reader, with his intellectual and psychic experience, with his associative thinking. So the interaction is between the reader and the text that presents the author's world. "Understanding is an essential feature of communication. Without understanding there is no communication" (Parijkova L. 2013a, p. 41).

One of the major components of reading literacy is the reflection. Reading is not just physical skill, but a way of dealing with problems, to create meanings. 
The reading competence is extremely important social competence, without reading competence we would not be able to develop ourselves, not develop our spiritual levels. It is also guaranty for our social and economic progress (Idem 2013c, p. 51).

\section{Factors that influence the reading competence}

Sociological studies have evaluated multiple features such as:

- socio-demographic profile of readers,

- the proportion of people who read books in their spare time and the proportion of those who prefer other pursuits,

- motivation of people to read books,

- the need for public libraries and community centers,

- reasoning in the selection of books,

- preferred genres,

- alternative leisure activities, etc.

Teach your child to love books as a little and you will to stay calm later - said a popular Bulgarian blogger. It is important to determine the motive of reading, the subject's need to understand the information, the desire for self-improvement and self-assertion. The development of needs and reading practices from an early age will help to our children and young generation to ensure a sustainable interest in reading and it will guarantee higher social and cultural status in the future.

As many printed texts children know such more comfortable they will feel themselves with the books and they will understand that the print is useful. School-age children will already know how to deal with the books and know how to follow the words on the page. They acquire an interest in books and begin to enjoy them. Children who like their parents reading for them will want to learn to read early. These kids will have a motivation to read (Stoykova D. 2013, p. 68).

All studies highlight the role of the family to nurture love of reading. Economic environment has also an influence on reading competence. Naturally, the children of well-educated parents with good social status do better in school than their schoolmates from poor and uneducated families.

The main factors that form the skills and desire for reading are family, school, personal qualities. Important for the formation of good readers are the conditions that the kids grow up - how many books there are in family, whether parents read to their children, whether they give good example, if the child reads under obligation or for pleasure, etc.

The researchers Sandersten Holte and P. Cruz considered that a reading culture in a society may improve when there is a wish to improve conditions for reading at home, at school and in the community at the same time. Improving the image 
of the reading should be a priority of the school (Sandersten H. M. 1998; Cruz P. C. 2003).

The development of a necessity and practices of reading from early ages contributes and builds a sustainable interest in reading and helps achieving greater social and cultural status. The students also need of reading stimulating's strategies (Parijkova L. 2012c, p. 21).

\section{Some facts about reading culture in Bulgaria}

Bulgaria occupies second to the last place in the representative survey, which took place in early 2012 among 44 countries by international study of PISA by the Organization for Economic Cooperation and Development (OECD). In the presentation the plan for dealing with illiteracy in the EU the European Commission reported that $41 \%$ of Bulgarian students are in some aspects illiterate. Almost every second of them has trouble with reading and understanding the text in their native language. Most of Bulgarian young people unfortunately grow up without books, they find reading as "waste of time" (OECD 2010).

The process of reading is connected with a complex mental activity that can easily be replaced by a world of images of the plasma screen of TV set or of smartphone's games. More than $50 \%$ of the three year old children have a television set and 20 percent of parents do not read to their children - is found in the press release, which gives information about a national campaign to promote reading among young children (Study after the first stage of the national campaign "Fairy celebration with Pom Bear", 2009). Only 7.10\% among the surveyed students indicated that they read every day.

The state regulation in the field of the taxation for books has not changed. In Bulgaria there is $20 \%$ VAT on books. Only in Denmark it is higher - by $25 \%$. As the Author knows in Great Britain, Ireland and Norway VAT on books is zero.

One Bulgarian poet says that it was more important how many books came in our heads than how many books were accounted per capita of Bulgaria. But no matter how increasing numbers of research and events related to the book, they mostly are made of concrete libraries, of small NGOs, of volunteers, banks, etc. That's why we couldn't talk about a shared national agenda, a Bulgarian strategy even less - about policy. Bulgaria has no policy to promote reading (Parijkova L. 2013c, p. 52-53).

\section{Good practices for reading stimulation in Bulgaria}

There is an official organization, connected with books - Bulgarian Book Association (http://www.abk.bg/). It provides many initiatives like "Book's Fairs" (twice per year), award "Knight of the book", "March of books" and so on. 
Big Reading is a campaign broadcast on Bulgarian National Television, in order to consult the Bulgarians for their favorite novels. The transmission is based on the British format of the Big Read BBC. Started in Bulgaria on October 5th, 2008 and ended on March 22nd, 2009. Voting was done through SMS, via the Internet, by telephone or by letter. Initially selected 100 novels (21st December 2008), from which subsequently were classified first 12. Under the Yoke (Pod igoto) from the most famous Bulgarian author Ivan Vazov was on the first place. Variation of this initiative is a little Big Reading for children's books. Pippi Longstocking of Astrid Lindgren was on the first place and JK Rowling's Harry Potter on the second place.

On May 14th 2014 for the third time in Bulgaria simultaneously in all participating cities and countries were held public readings of works by European authors. There was "Reading in unconventional urban spaces". Famous actors or public figures presented literature of different countries - Night of the literature. "Fun Summer Reading" is an initiative of Bulgarian portal for children Az-deteto. bg, Sofia City Library, which aims to promote reading as fun among children. The initiative conducts annual major campaigns during the months of summer vacation and has nationwide coverage. Exchange plastic scrap for Books - this campaign has a great interest. The citizens of the capital transferred plastic bottles and receive a book. The "Books in the subway" was held on the occasion of the Day of Bulgarian Enlightenment and Culture and Slavonic Alphabet - 24 May. In the Sofia's subway there are shelves of books in various genres that everyone who may get free and read while waiting for the next train or travel. In one of the most popular Bulgarian Black Sea resorts a library on the beach is created. BookShare is an initiative of two young ladies who have lived abroad. They defined BookShare as a community that creates an environment for people who are familiar with reading books. "Library between the leaves" is an initiative of citizen's organization that put a bookcase with many books in the courtyard of the park. Читать не вредно - вредно не читать! It is not harmful to read harmful is not to read! - this is the slogan of popular already in Bulgaria Russian project that stimulates students each week reading a book. Teachers, students and parents are involved in the project (Читать не вредно... 2014). Initiative of the shopping center "Share a book for the summer" - in the lobby of a large mall is placed a Bookcase, where everyone can leave his favorite book and take another to read it. ProCredit bank encourages reading with creation libraries in the head office of the bank and its branches.

In our country very popular method for reading stimulation is a recommendation from a friend or from people who are the same age as yours. That's why there are some sites and blogs which recommend books, authors and which give an opportunity for creation reader's clubs. The largest website for books and reading 
in Bulgaria - "I read" is the first "online media for books". The reading campaign "The Time Machine" organized by the website "I read" and aimed at promoting reading among children of primary school is the World Day of Roald Dahl. It happens within 3 months and targets all children aged 7 to 13 years who have read three books by Roald Dahl, published in Bulgarian and then sent a special form of participation. "Reading is the latest retro pleasure" - said the most famous blogger Christo Blajev whose "Knigolandia" has 10 thousand followers. He wrote 1000 reviews of books and described himself as professional reader. Site "Pass forward a book" (http://knigi.vremeto.org) is a reading club for exchange books. Through it have been passed books from hand to hand. Specialized site "Children's Books" (http://detskiknigi.com) offers various ways to promote reading among children. Sunflowers (slunchogledi.bg) is a portal for reading promotion, which has a bibliographic data base, option for quick search, statistics of books that were read and glossary of literary terms. According to its creators portal is a powerful tool for building the prestige of the teacher and the school. Cheti.ME (http://cheti.me) is a site for free sharing books. It is a free virtual library where everyone can give or borrow a book.

The basic philosophy of this type of blogs (or sites) for books is that young people usually have no interest in opinion of older. They can hear or read review from a friend or a coeval. Therefore, online-based reviews of books have been written from the position of young readers (Parijkova L. 2013e, p. 203).

\section{Initiatives of the State University of Library Studies and Information Technologies}

The State University of Library Studies and Information Technologies (SULSIT) always had an engagement to achieve the construction of a complex, creative, and innovative environment, including relevant support of communication infrastructures, and deployment of heterogeneous social capital by nature. As a scientific, educational, and cultural institution, our university has a mission to stimulate spiritual activities of young people. The university has always had the purpose to stimulate reading and recognizes the crucial role of the book and education as key factors in personality development.

Reading is a highly valuable skill and activity and our university has started many initiatives, connected with reading promotion. Since 2011 SULSIT has celebrated the World Book and Copyright Day with many events. The date 23rd April was chosen by UNESCO back in 1995 to pay a worldwide tribute to books and their authors.

The university's initiatives are highly varied. Students read and recite an American poetry; students, who have studied the Rhetoric, read stories to kids. There 
was also a "Round Table" where Bulgarian writers and famous directors discuss issues related to the book and reading. The contest for essays "The Book of My Life" was provocative for the students. They were honest and original. There was the contest for posters too. There have been also many exhibitions - with valuable, rare, and antique books. Very creative was the workshop, where students made their own books. SULSIT awarded people who have achievements in the field of protection of the book with prizes "Homo Legens". We also printed a book collection with scientific reports.

In 2012 the State University of Library Studies and Information Technologies hosted a scientific conference on the book and the copyright process. The participants were leading scientists, lecturers, publishers, booksellers, journalists, specialists, and students. There was very interesting discussion about the role of new stimuli for reading promotion. One of these stimuli is the reading of books-games. In Bulgaria there is a renaissance of this kind of books. Its audience is young people and children. The books-games allow readers to create their own contents when they have been doing their choices. As we know the philosophy of books-games is connected with free choices which the reader should make after each chapter. In this way the action in the book can move in different ways. The current users have a necessity of entertainment and the active participation in the creation of the book's subject is kind of challenge which may give pleasure for them.

The next initiative was the reading of our rhetoric students to schoolchildren. We tried to study our students to be familiar with the idea of reading promotion. As a result we have many little readers and enthusiastic students. Of course we cannot decide the main problem in our country - the lack of a national strategy of reading comprehension.

We only try to encourage young people, to discover the pleasure of reading. In 2012 we also organized students' essay competition. Our goal was to provoke their imagination about "The Reading..." and its role nowadays. We also made a competition for poster, dedicated to the World Book and Copyright Day.

This year (2014) we had also events. Some of them were: the initiative "Let Freedom to Books" in the courtyard of our university SULSIT - students and teachers brought books to our bookcrossing zone, award "Homo Legens", contents of student's essays and posters, children's exhibition, an exhibition of books without the books "In the shadows of the books", discussion "Book - between stereotypes and reality" with the participation of leading Bulgarian and American scientists, publishers and bloggers involved with the book and its social importance, Night at the Library, where fans of the written words read their works until midnight, session of students, scientific session "Book - our more sensual present", a workshop for making clothes for books and so on. 
Our efforts to promote reading were approved by UNESCO, and it presented our university's initiatives three times in its official site (UNESCO 2011, 2012, 2014).

With our initiatives we try to increase confidence in reading. We can also help students recognize the role of the book as a factor in personal success, that's very important for them. In my opinion the project's team should make popular the idea that reading is cool, enjoyable and useful activity. We should motivate an audience and search for an emotional moment to attract youth.

The project "New Policies for Stimulating the Reading. Research of the Bookcrossing Practices in Bulgaria" (started December 2011) fueled by the Bulgarian Science Fund, Young Researchers, with a project manager assoc. prof. Lubomira Parijkova, $\mathrm{PhD}$, analyzes the "Bookcrossing" phenomenon. The team consists entirely of young scientists and $\mathrm{PhD}$ students - philosopher, historian, philologist, linguist, psychologist, and pedagogue.

The aim of the project is to investigate new phenomena related to reading and to seek opportunities to their inclusion in its promotion strategies. The project stimulates dialogue about the place of books and reading in our life and the academic community. The reading could be a resource for spiritual revival of the Bulgarian society. It is focused on contemporary phenomena which expresses the love for books in Bulgaria such as: "bookcrossing," sites and blogs about books, book-cafes, etc. We started to analyze the accumulated information from existing sites which promote books and researching for the topic of "bookcrossing" in foreign literature.

The global phenomenon "bookcrossing" was born in March 2001, when Ron Hornbaker, a computer specialist, decided to leave his own book to unknown readers. He created the website: www.bokcrossing.com on 17th April in the same year. Thirteen years later, 1,729,023 people of different ages and demographic characteristics, from 132 countries, were registered in this site. They transferred 10,365,799 books (Bookcrossing 2014). BookCrossers love their books and love to read them. They tend to be the most generous, innovative, earth-friendly, good-hearted, whimsical, fun and educated people on the face of the planet (Ibidem).

"Bookcrossing" looks like a game. "Bookcrossing" means the place where the roads of books or practice of certain public places be left "in the wild" books, then someone is also ideally reading and commenting. Movement includes a worldwide community of people who are interested in books and love to read them. Bookcrossing includes the desire to communicate with other people on the internet to discuss specific readings, search and exchange of information and even postage traditional books. Bookcrossing's motto is "read and release". Extremely attractive physical "release" of the books (also known as "wild release" or "release into the wild"), which adds an element of gaming initiative. It is a network of free 
books which readers may exchange. The philosophy of this project is clear: not to own, only to read a book. This is the main worth of the online community a reading society. The word "bookcrossing" has been added to Oxford dictionary and means: the practice of leaving a book in a public place to be taken and read by someone who then leaves it there again.

"Bookcrossing" works like this: each book is marked with a special sticker that carries information about the initiative. The bookcrossers (people who play this amusing game) register books online at www.bookcrossing.com and may see where the book was. The "bookcrossing" area or "zone" is a place where the books cross paths and where you may release a book into the flow. There are zones like these in large Bulgarian towns and cities.

As a recent phenomenon, born of a love of books and, the "Bookcrossing" can stimulate interest in reading. For our case study's purpose we created a "bookcrossing zone" on the campus. We bought books, registered them in www.bookcrossing.com, marked them with "bookcrossing" labels, and released them. Our aim is to follow the book's movement and to research what kind of books is more interesting for the students, how many places the books may change and other interesting for the reading promotion cases.

In this project we created a documentary film-portrait of Bulgarian scientist and poet Peter Parijkov. He was a respected Professor, who dedicated his life to researching the history of books, the Bulgarian Revival and bookselling. He was also a poet and a staunch patriot. He devoted himself to fueling the Bulgarian spirit and culture. Our team of young scientists realized the idea for giving to the young people a model of person who dedicated his life to the Book.

Another method of stimulating reading and book love in higher education is conducting a series of students' meetings with Bulgarian authors. The project's goal is to create a "book cafe'" in SULSIT where discussions of books, readings, courses on creative thinking etc., can be implemented. The "book-café" project allows the formation of an academic community that continuously improves its competence and provides interaction with publishers, book distributors, and associations, and contributes to full dialogues, openness, tolerance and awareness.

As university teachers we have a responsibility to search answers to the question: How to make reading attractive to young people? We should work on their motivation for reading. And I hope that some of them will feel the need of books.

\section{Conclusions}

The easiest way for reading stimulation among any audience happens when an individual subject is already addicted to reading, when he reads with pleasure any texts - scientific, literary, it doesn't matter. Young generation should have 
positive attitude, to see opportunities, to see good examples from their parents, their teachers and friends. It is necessary publishers know their readers, to invest in getting to know them.

It is necessary at the national level to take measures for the accessibility of the book, for improving the literacy of the population, for reading promotion. Reading should be necessary and desirable daily activity.

In conclusion, it should be noted that the development of competence in children readers and students is the responsibility of all of us - parents, libraries, schools, NGOs, media, publishing and the whole society. Because without book we cannot develop ourselves spiritually nor communicate normally. The book is a basic value of culture. In times of crisis it is important to turn to the book and to the wisdom that the book gives to us. It is necessary to return public prestige of reading.

\section{References}

Bookcrossing (2014) [online], [accessed: 01.06.2014], retrieved from Internet: $<$ http://www.bookcrossing.com/>

Chantov V. (2012), Competency and Competence (between knowledge and ability). New information technologies in educational process, Sofia, Publishing house „Za bukvite - O pismeh", ISBN 978-95-49-94630-4

Читать не вредно - вредно не читать! (2014) [online], [accessed: 15.11.2014], retrieved from Internet: <https://sites.google.com/site/chteniesuvlecheniem/home/>

Cruz P. C. (2003), The library and the promotion of reading [online], "CNDLAO Newsletter", no. 48, November, [accessed: 15.11.2014], retrieved from Internet: <http://www.ndl.go.jp/en/cdnlao/newsletter/048/484.html/>

International Reading Association (2014) [online], [accessed: 15.11.2014], retrieved from Internet: <http://www.reading.org/>

OECD. Education at a Glance: OECD Indicators (2010) [online], [accessed: 15.11.2014], retrieved from Internet: <http://www.oecd.org/document/52/0 ,3746,en_2649_39263238_45897844_1_1_1_1,00.html/>, ISBN 978-9264-05598-8

OECD (2010), PISA 2009 results: what students know and can do - student performance in reading, mathematics and science [online], Vol. 1, [accessed: 15.11.2014], retrieved from Internet: <http://www.oecd.org/document/61/0 ,3746,en_32252351_32235731_46567613_1_1_1_1,00.html>, ISBN 97892-64-09145-0

Parijkova L. (2012a), The Experience of SULSIT for reading stimulation. Bookcrossing and initiatives related to the exchange of books. Information literacy - training 
models and best practices, Sofia, Publishing house "Za bukvite - O pismeh”, ISBN 978-954-2946-30-4

Parijkova L. (2012b), The Research of the site www.bookcrossing.com. The Bookour more sensual present, Sofia, Publishing house "Za bukvite - O pismeh”

Parijkova L. (2012c), The Book - Our More Sensual Present, "The International Journal of the Book", vol. 10, issue 4, p. 19-27

Parijkova L. (2013a), Interaction vs. Communication, Sofia, Publishing house „Za bukvite - O pismeh", ISBN 978-954-2946-63-2

Parijkova L. (2013b), Bookcrossing and initiatives related to the exchange of books. Study and presentation of good practices for reading competence of children and students, Sofia, Publishing house „Za bukvite - O pismeh”, ISBN 978-9542946-92-2

Parijkova L. (2013c), Government policy for reading stimulation [in:] Parijkova L. (ed.) The Book - our more sensual present, Sofia, Publishing house „Za bukvite - O pismeh"

Parijkova L. (2013d), Research of current tendencies in the field of the book and reading. Digital present and future: economic, cultural, educational, legal and technological impacts, Sofia, Publishing house „Za bukvite - O pismeh”

Parijkova L. (2013e), Sites for sharing books and for book's reviews. Study and presentation of good practices for reading competence of children and students, Sofia, Publishing house „Za bukvite - O pismeh”, ISBN 978-954-2946-92-2

Sandersten Holte M. (1998), Creating an optimum reading culture in the low countries: the role of Stichting Lezen [online], [accessed: 15.11.2014], retrieved from Internet: <http://archive.ifla.org/IV/ifla64/098-80e.htm/>

Stoykova D. (2013), From love to read to success in reading [in:] Parijkova L. (ed.) The Book - our more sensual present, Sofia, Publishing house „Za bukvite - O pismeh"

\begin{abstract}
The paper presents some good practices for reading stimulation in Bulgaria. The focus is on young people and students. Dr. Parijkova defines the term reading competence. The main thesis is that achieving reading competence of children readers and students need to target the collaboration among agencies, schools, public and school libraries, publishers, NGOs and parents. The good practices are shown as activities of mediators of reading publishers, booksellers, teachers, librarians, media, banks.

She also describes her experience for reading stimulation among students at the university where she teaches. Since 2011 Dr. Parijkova has organized a conference about the book, reading and copyright in the State University of Library Studies and Information Technologies. Some initiatives are Round Table, which discuss issues related to Book and Copyright, a workshop, where students make their own hand-made books, presentations
\end{abstract}


of books and authors, interviews with young Bulgarian writers, Bookcrossing-zone, contests for essays and posters on theme "The Book of my life", exhibition of antique, rare and valuable books, students read books to children, awarding of prizes for achievements in the field of protection of the book and raising it as a spiritual companion to modern human.

The presentation is in the context of developing a policy for reading and increasing the prestige of the book. The author also shows her team research on reading attitude and some reading tendencies in Bulgaria.

\begin{abstract}
Abstrakt
W tekście zaprezentowano niektóre dobre praktyki w zakresie wspierania czytelnictwa w Bułgarii, ze szczególnym uwzględnieniem młodzieży i studentów. Autorka definiuje termin „kompetencji czytelniczych”. Główną tezą jest założenie, że osiągnięcie kompetencji czytelniczych przez dzieci i uczniów wymaga współpracy pomiędzy instytucjami, szkołami, bibliotekami szkolnymi i publicznymi, wydawcami, organizacjami pozarządowymi oraz rodzicami. Dobre praktyki pokazane są jako działania pośredników czytania - wydawców, księgarzy, nauczycieli, bibliotekarzy, mediów, banków. Autorka opisuje również swoje doświadczenia w zakresie wspierania czytelnictwa wśród studentów uniwersytetu, na którym wykłada. Od 2011 r. Parijkova zorganizowała konferencję na temat książki, czytania i praw autorskich w Państwowym Uniwersytecie Nauk o Bibliotece i Technologii Informacyjnych. Pośród inicjatyw można wymienić Okrągły Stół, podczas którego omawia się zagadnienia związane z książką i prawami autorskimi, warsztaty, podczas których studenci tworzą własne ręcznie robione książki, prezentacje książek i autorów, wywiady z młodymi bułgarskimi pisarzami, strefa Bookcrossingu, konkursy na eseje i plakaty pod hasłem „Książki mojego życia”, wystawa zabytkowych, rzadkich i cennych książek, studenci czytający książki dzieciom, przyznawanie nagród za osiągnięcia w dziedzinie ochrony książki.

Artykuł powstał w kontekście rozwoju polityki czytania i zwiększenia prestiżu książki. Autorka pokazuje również wpływ badań swojego zespołu na postawę czytelniczą, a także na niektóre tendencje do czytania w Bułgarii.
\end{abstract}

